Яхьяев М.Я. Факторы воспроизводства экстремизма и терроризма в современной России: комплексный анализ // Исламоведение. 2016. № 3. С. 26-39.

$\begin{array}{lll} & \text { ISLAM IN RUSSIA } \\ & \text { ИСЛАМ В РОССИИ } & \text { Responsible for the section: } \\ \text { Ответственный за рубрику: Малашенко A.B. } & \text { Malashenko A.V. } \\ \text { ○ Исламоведение, 2016. Том 7, № 3 (29) } & \begin{array}{l}\text { C Islamovedenie, 2016. Vol. 7, № 3 (29) } \\ \text { Онлайн-доступ к журналу: http://islam.dgu.ru }\end{array} & \begin{array}{l}\text { Online access to the journal: } \\ \text { http://islam.dgu.ru }\end{array} \\ & & \end{array}$

\begin{tabular}{|c|c|c|}
\hline У ДК 297.1/323.285 & Содержание статьи & Информация о статье \\
\hline DOI: 10.21779/2077- & Введение & Поступила в редакцию: 20.03.2016 \\
\hline 8155-2016-7-3-26-39 & $\begin{array}{l}\text { Экстремизм как конкретно-исторический } \\
\text { социальный феномен }\end{array}$ & $\begin{array}{l}\text { Передана на рецензию: } 21.03 .2016 \\
\text { Получена рецензия: } 25.05 .2016\end{array}$ \\
\hline М.Я. Яхьяев & $\begin{array}{l}\text { Социальные истоки и причины } \\
\text { экстремизма в России } \\
\text { Заключение }\end{array}$ & Принята в номер: 25.07.2016 \\
\hline
\end{tabular}

ФГБОУ ВО «Дагестанский государственный университет», тисhtar59@таil.ru

В статье, исходя из того, что любые социальные феномены имеют конкретноисторический характер, анализируется глубинная сущность общественной и личной деструктивности экстремизма и терроризма, решаются методологические вопросы разграничения общего и единичного в их проявлениях. В ней утверждается возможность разработки и реализации комплексной программы противодействия экстремизму и терроризму на основе выявления объективных и субъективных, внутренних и внешних причин его воспроизводства. Представленный в статье анализ предлагает ответ на вопрос, почему же в России, несмотря на затратные усилия органов власти и институтов гражданского общества, не удается нейтрализовать экстремистскую идеологию и снизить активность террористического подполья; предлагаются пути повышения эффективности антиэкстремистской идеологической и практической работы. Автор приходит к выводу, что в основу комплексной программы противодействия экстремизму должно быть заложено его определение как способа социально-политической деятельности организованных сообществ, мотивированного исключительно экстремистской идеологией. Если в основе деструктивной деятельности конкретного субъекта социального действия нет такой идеологии, то нет и экстремизма, а имеют место проявления бандитизма, организованной преступности и прочего криминала.

В статье утверждается возможность предотвращения превращения нормальной идеологии в экстремистскую по мере гуманистического реформирования общества, осуществления системных, комплексных социально-экономических и политико-правовых преобразований, радикально меняющих системное качество современного российского общества, устраняющих объективные причины и глубинные истоки экстремизма, который по своей сути является иллюзорной, утопической, разрушительной формой деятельности, не улучшающей социальное или политическое положение людей, а только направляющей, канализирующей в ложное, деструктивное русло их стихийную, спонтанную агрессию.

Ключевые слова: экстремизм, терроризм, профилактика, борьба, религия, ислам, идеология, власть, гражданское общество, социальная деструктивность.

\footnotetext{
* Мухтар Яхьяевич Яхьяев - заведующий кафедрой философии и социально-политических наук, д. филос. н., профессор, ДГУ.
} 
Yakhyaev M.Ya. The Factors of Extremism and Terrorism Reproduction in Contemporary Russia: Comprehensive Analysis. Islamovedenie. V. 7, № 3. P. 26-39

UDK 97.1/323.285

DOI: $\quad 10.21779 / 2077-8155-$ 2016-7-3-26-39

M.Ya. Yakhyaev *
The content of the article

Introduction

Extremism as a specific historical social phenomenon

Social origins and causes of extremism in

Russia

Conclusion
Information about the article

Received: 20.03.2016

Submitted for review:

21.03.2016

Received to review: 25.05 .2016

Accepted in: 25.07.2016

\title{
The Factors of Extremism and Terrorism Reproduction in Contemporary Russia: Comprehensive Analysis
}

\author{
Dagestan State University; muchtar59@mail.ru
}

Proceeding from the idea that all social phenomena have a specific historical nature, the author analyzes the in-depth causes of the social and personal destructiveness of extremism and terrorism, and attempts to resolve the methodological issue of delimitation of the general and the sporadic in their manifestations. The author maintains that there is a possibility to develop and implement a comprehensive program to combat extremism and terrorism on the basis of the identification of objective and subjective, internal and external factors of its reproduction. The study offers an answer to the question why Russia, despite the costly efforts of the authorities and institutions of civil society, fails to neutralize extremist ideology and to supress the activity of the terrorist underground and suggests ways to improve anti-extremist ideological and practical work. The author arrives at the conclusion that the comprehensive program of counteraction to extremism should be based on its definition as a method of socio-political activities of organized communities motivated solely by extremist ideology. If the destructive activities are not based on ideology, there is no extremism, rather it is a manifestation of banditry, organized crime and other criminal activities. The author maintains there is an opportunity to prevent turning a normal ideology into an extremist one if the society is committed to humanist reforms, comprehensive socio-economic and legal transformations that will radically change the systemic quality of the contemporary Russian society by eliminating the objective causes and indepth sources of extremism, which inherently is an illusory, utopian, destructive activity that does not improve the social or political status of people, but just gives a false, destructive direction to their natural, spontaneous aggression.

Keywords: extremism, terrorism, prevention, fight, religion, Islam, ideology, power, civil society, social destructiveness.

\section{Введение}

Проблема экстремизма и терроризма приобрела для российского общества за последние годы особую злободневность. Так, по информации Генеральной прокуратуры РФ, преступлений экстремистской направленности в 2009 г. было зарегистрировано 548, в 2015 году - 1308, а уже в январе-мае 2016 года - 666. Преступлений террористического характера в 2009 году было зарегистрировано 654, в 2015 г. - 1531, а в январе-мае 2016 г. - 1025 [2]. Подобная динамика проявлений экстремизма и терроризма настоятельно требует научно обоснованной, последовательной, комплексной программы действий органов власти и институтов гражданского общества, направленной на профилактику и предупреждение проявлений этих форм социальной деструктивности. Однако разработка такой программы невозможна

${ }^{*}$ Mukhtar Yakhyaevich Yakhyaev - Doctor of Sc. (Philosophy), professor, head of the Philosophy and Socio-Political Sciences Department of Dagestan State University 
Яхьяев М.Я. Факторы воспроизводства экстремизма и терроризма в современной России: комплексный анализ // Исламоведение. 2016. № 3. С. 26-39.

без системного, подлинно научного осмысления главных объективных и субъективных, внутренних и внешних причин и факторов их воспроизводства и активизации.

Проблема экстремизма и терроризма сложна и многогранна, она не имеет простых, однозначных (исключительно социально-экономических, политико-правовых, силовых или пропагандистско-воспитательных, образовательных) решений. Важным условием, предваряющим ее решение, является выяснение того, каковы же подлинные истоки, корни и причины, подпитывающие эти разрушительные явления; почему не удается нейтрализовать экстремистскую идеологию и минимизировать основывающуюся на ней террористическую деятельность; как повысить эффективность антиэкстремистской работы государства и общества и пр.?

В предлагаемой статье предпринимается попытка объективного, беспристрастного анализа экстремизма и терроризма как деструктивных для общества и личности феноменов. Основными аспектами рассмотрения в ней являются: 1) определение предмета анализа на основе выявления глубинной сути экстремизма, бандитизма и терроризма; 2) осмысление глобальных общих и специфических, объективных и субъективных, внутренних и внешних причин воспроизводства экстремизма и терроризма; 3) установление наиболее эффективных направлений и мер профилактики экстремизма и терроризма в современном российском обществе. Отдельные исследования по данной проблеме отражены в работах: Белокурова Г.И. [1], Зинченко Ю.П. [10], Матчановой 3.Ш. [5], Пайн Е.Л. [7] и др.

\section{Экстремизм как конкретно-исторический социальный феномен}

Основными предметами нашего анализа являются экстремизм как конкретный социально-исторический феномен и экстремист как единичный социальный субъект - носитель экстремистских идей и практических действий. Выдвижение этих явлений в центр рассмотрения обусловлено тем, что нередко в научных публикациях, нормативно-правовых документах, выступлениях политиков, победных реляциях силовых органов наблюдается стихийное или преднамеренное смешение или даже подмена понятий «экстремизм» и «терроризм», «экстремист» и «террорист». А подобные случаи чаще всего провоцируются отсутствием однозначных научных определений, схватывающих глубинную сущность этих феноменов. Приведу несколько красноречивых примеров.

Первый представлен в Федеральном законе № 114 «О противодействии экстремистской деятельности», который приравнивает экстремистскую деятельность к экстремизму, констатируя, что экстремистская деятельность (экстремизм) есть насильственное изменение основ конституционного строя. Далее закон уточняет понятие экстремистской деятельности, раскрывая ее содержание посредством простого перечисления основных форм и разновидностей экстремистских действий, к которым среди прочих отнесены:

- «нарушение целостности Российской Федерации;

- публичное оправдание терроризма и иная террористическая деятельность;

- возбуждение социальной, расовой, национальной или религиозной розни;

- пропаганда исключительности, превосходства либо неполноценности человека по признаку его социальной, расовой, национальной, религиозной или языковой принадлежности или отношения к религии;

- нарушение прав, свобод и законных интересов человека и гражданина в зависимости от его социальной, расовой, национальной, религиозной или языковой принадлежности или отношения к религии;

- воспрепятствование осуществлению гражданами их избирательных прав и права на участие в референдуме или нарушение тайны голосования, соединенные с насилием либо угрозой его применения; 
Yakhyaev M.Ya. The Factors of Extremism and Terrorism Reproduction in Contemporary Russia: Comprehensive Analysis. Islamovedenie. V. 7, № 3. P. 26-39

- воспрепятствование законной деятельности государственных органов, органов местного самоуправления, избирательных комиссий, общественных и религиозных объединений или иных организаций, соединенное с насилием либо угрозой его применения;

- совершение преступлений по мотивам, указанным в пункте "e" части первой статьи 63 Уголовного кодекса Российской Федерации;

- пропаганда и публичное демонстрирование нацистской атрибутики или символики либо атрибутики или символики, сходных с нацистской атрибутикой или символикой до степени смешения;

- публичные призывы к осуществлению указанных деяний либо массовое распространение заведомо экстремистских материалов, а равно их изготовление или хранение в целях массового распространения;

- публичное заведомо ложное обвинение лица, замещающего государственную должность Российской Федерации или государственную должность субъекта Российской Федерации, в совершении им в период исполнения своих должностных обязанностей деяний, указанных в настоящей статье и являющихся преступлением;

- организация и подготовка указанных деяний, а также подстрекательство к их осуществлению;

- финансирование указанных деяний либо иное содействие в их организации, подготовке и осуществлении, в том числе путем предоставления учебной, полиграфической и материально-технической базы, телефонной и иных видов связи или оказания информационных услуг» [ФЗ № 114 «О противодействии экстремистской деятельности»].

В нормативных документах подобное определение экстремизма закрепилось по той причине, что некоторые авторитетные ученые и эксперты в своих исследованиях годами повторяют одни и те же абстрактные определения этого явления, перечисляя отдельные характерные для него признаки, среди которых чаще всего называются:

1) публичные призывы к установлению в России диктатуры, то есть строя, значительно ущемляющего политические и гражданские права граждан России;

2) публичные призывы к насильственному свержению конституционного строя или к захвату власти;

3) создание вооруженных формирований;

4) разжигание социальной, расовой, национальной, языковой или религиозной розни и публичное выражение намерений ограничить права граждан по этим признакам;

5) представление своих целей, идеалов или отличительных признаков с помощью символики, в недалеком прошлом присущей национал-социалистическому режиму Германии и фашистскому режиму Италии;

6) публичное одобрение национал-социалистических, фашистских и иных тоталитарных режимов; отрицание преступлений, совершенных такими режимами, оправдание их лидеров и политики [4].

Еще чаще в научном сообществе экстремизм определяется как приверженность к крайним взглядам и действиям, которая порождает кризисы социально-экономического порядка, отклонения в развитии политических институтов, снижение уровня жизни населения; вызывает рост чувств и настроений социальной бесперспективности и личной нереализованности, провоцирует страх перед будущим, подавление властями оппозиции и инакомыслия, блокирование легитимной самодеятельности индивида, национальный гнет, амбиции лидеров, политических партий, ориентации лидеров политического процесса на экстремальные средства политической деятельности [3]. Еще менее удовлетворительным является обнаружение сущности экстремизма в его характеристике как вида «девиантного поведения» [8].

Подобные формулировки появляются вследствие того, что исследователи не утруждают себя выявлением сущностных характеристик подлежащего определению феномена. Так, 
Яхьяев М.Я. Факторы воспроизводства экстремизма и терроризма в современной России: комплексный анализ // Исламоведение. 2016. № 3. С. 26-39.

на 17 Международной научно-практической конференции «Терроризм и экстремизм как угрозы национальной безопасности России...», проходившей в г. Нальчике КБР, профессор М.П. Киреев, отмечая понятийную разноголосицу, предлагал заложить в нормативноправовые документы определение экстремизма как преступного действия, характеризующегося антигосударственной направленностью, а терроризма - как преступного действия, имеющего общественно опасный характер. Ученый, наверное, забыл, что главной целью науки, в том числе юридической, является объективный и всесторонний анализ реального социального феномена, установление его глубинной сути и последующая понятийная фиксация. И таких примеров, к сожалению, обнаруживается множество в выступлениях и публикациях не только политических деятелей, но и исследователей-экспертов.

Нам представляется, что ни одна из приведенных трактовок экстремизма (а их перечень можно продолжить) не является определением, фиксирующим глубинную сущность этого конкретно-исторического социального феномена, так как ни одна из них не учитывает конкретные мотивы действий и поступков, квалифицируемых как проявления экстремизма. А это является крайне важным по той простой причине, что одни и те же деяния, например организация и участие в массовых беспорядках, совершение хулиганских проступков, осуществление актов вандализма и пр., могут иметь совершенно различную мотивацию. Мотивом подобных противоправных действий может быть не только экстремистская идеология, но и стихийный социальный протест конкретного социального субъекта против действий властей, ущемляющих его интересы, или что-либо другое. Но в силу того, что в определении экстремизма, отождествляющем его с экстремистской деятельностью, или перечисляющем его внешние признаки ничего не говорится об идеологии, лежащей в основе экстремизма, с ним легко отождествить любые радикальные действия, в том числе и те, которые не имеют отношения к экстремизму. А отождествление экстремизма с терроризмом на основе их объединения по внешним признакам имеет давнее и устойчивое хождение: «Самое крайнее выражение политического экстремизма представляет собой терроризм - систематическое устрашение, провоцирование, дестабилизация общества насилием» [Экстремизм // Мир словарей // http://mirslovarei.com/content_pol/JEKSTREMIZM1365.html]. Ущербность таких подходов заключается и в том, что, во-первых, перечисление экстремистских действий или их признаков никогда не может быть исчерпывающим, а вовторых, в подобном перечне легко оказываются и явления, не имеющие экстремистской направленности.

Избежать логического отождествления экстремизма с терроризмом или же бандитизмом мы можем, указав на то, что в понятии «экстремизм» фиксируется особенный, чрезвычайный способ социального действия, который содержит в себе такие ключевые моменты, как идеология, мотивация цели и специфические средства воздействия. В отличие от экстремизма понятие «террор» схватывает только один из видов противоправного действия и потому вырастающий на его основе терроризм в содержательном отношении значительно уже экстремизма. Террор - это всего лишь один из способов политического действия, заключающийся в угрозах использования или действительном использовании неправовых, жестких, жестоких, насильственных действий (физических или психологических) против оппонентов. Он имеет целью уничтожение, подавление, сдерживание или запугивание противников. «Террор - это состояние очень сильного страха (ужаса), возникающее как реакция на нечто (некоторые действия), имеющее целью вызвать именно это состояние у тех, в отношении кого осуществляются данные действия, или же тех, кто является их свидетелем... Террор складывается из террористических актов - отдельных слагаемых, звеньев, компонентов, способов и инструментов террора» [6, с. 16].

Превращение подобных действий в упорядоченную систему, в способ социальной активности конкретного субъекта позволяет говорить о терроре как организованной системе террористических действий, специфической форме политической деятельности, иначе гово- 
Yakhyaev M.Ya. The Factors of Extremism and Terrorism Reproduction in Contemporary Russia: Comprehensive Analysis. Islamovedenie. V. 7, № 3. P. 26-39

ря, о терроризме как особом социальном феномене. В конечном счете терроризм по своей глубинной сущности оказывается определенным способом политической практики, который заключается в применении террористических средств и методов в борьбе с политическими противниками.

Все методы и средства террора (убийства, диверсии, взятие заложников, погромы, ограбления, уничтожение материальных и культурных ценностей, организация массовых беспорядков, шантаж и пр.) входят в арсенал экстремизма и зачастую занимают в нем самое видное место, однако экстремизм как форма социально-политической активности не исчерпывается террористическим арсеналом. Он может избирать и нередко выбирает иные средства помимо прямых разрушительных актов, пересекающихся с террором. Террористические акты являются лишь одним из способов реализации экстремистской идеологии, специфической формой борьбы с «неправильным» с точки зрения экстремистов миром. Но еще больше экстремизм отличается от терроризма на уровне идеологии. Все эти отличия делают теоретически корректным отнесение к экстремизму лишь таких действий, которые основаны и осуществляются во имя конкретной экстремистской идеологии, а не просто качественно отличаются от нормальных поступков своим крайним антигуманизмом. Иначе говоря, действительным экстремизмом является лишь такая деятельность, которая мотивирована исключительно экстремистской идеологией. Если в основе деятельности того или иного субъекта социального действия нет такой идеологии, то нет и экстремизма.

Таким образом, самой важной и значимой особенностью современного экстремизма является наличие в его основаниях специфической идеологии, которая и мотивирует экстремистскую деятельность. Экстремизм тем и отличается от бандитизма или простой уголовной преступности (в т. ч. организованной), что он обусловлен экстремистской идеологией. А это значит, что экстремизм ориентирован не на извлечение групповой или индивидуальной материальной выгоды, а на достижение идейно-политических целей. И таким иллюзорным, ложно понятым целям приносятся в жертву свои и чужие интересы, а нередко и сами жизни. Такими утопическими целями, как правило, являются: полное или частичное завоевание политической власти и обретение «независимости»; «освобождение» отдельных социальных групп, конфессиональных сообществ или даже целых народов, являющихся, по мнению самих экстремистов притесняемыми или угнетаемыми; утверждение нового социальноэкономического и политического порядка, являющегося «более справедливым», и т. д.

Иначе говоря, в основе экстремизма всегда находятся соображения идейного порядка. Более того, на определенных этапах своей активизации, особенно на начальной стадии, экстремисты могут ограничиваться одной только идеологической деятельностью, не прибегая к каким-либо практическим деструктивным социальным действиям. В этом мы и видим особенности феномена экстремизма по сравнению с иными, сходными с ним отрицательными социальными явлениями (бандитизмом, уголовной преступностью и пр.). Итогом сказанного становится необходимость разграничения экстремизма и терроризма, так как их преднамеренное или случайное смешение или подмена ведет к пагубным социальным последствиям.

В бандитизме, как и в организованной преступности, нет идеологического обоснования, т. к. банда - это всегда конкретное сообщество, ориентированное на извлечение материальной выгоды. Способом действия наиболее адекватным банде является террор, и поэтому преимущественными формами и средствами борьбы с ним являются именно силовые методы. Предупредить или подавить бандитизм проще, чем экстремизм, причина этого в том, что экстремизм невозможно характеризовать как оконченное преступление и подавить его силовыми методами на этапе разработки или пропаганды идеологии, которая сама постепенно приобретает экстремистские очертания. Поэтому методы и средства профилактики и предупреждения экстремизма не могут не отличаться от методов борьбы с бандитизмом. Исклю- 
Яхьяев М.Я. Факторы воспроизводства экстремизма и терроризма в современной России: комплексный анализ // Исламоведение. 2016. № 3. С. 26-39.

чительно силовыми методами преодолеть экстремизм невозможно, хотя подобным образом возможно кратковременное снижение накала экстремизма.

Приведенные характеристики отличительных особенностей экстремизма, терроризма и бандитизма требуют различения экстремистов, террористов, бандитов как единичных носителей экстремистской или террористической активности. Экстремист (террорист) - это конкретный индивид, который по тем или иным причинам оказался подверженным влиянию экстремистской идеологии и вовлеченным в сообщество или организацию, осуществляющую экстремистскую деятельность. Причин и путей вовлечения отдельного индивида в экстремистскую деятельность может быть столько же, сколько и самих экстремистов, и они существенно отличаются от причин и факторов воспроизводства экстремизма как социального явления. Но всем им должен быть поставлен социальный заслон.

В соответствии с существующей нормативно-правовой базой силовые органы обязаны пресекать деятельность как экстремистских организаций и сообществ, так и отдельных индивидов. Конкретные субъекты, вставшие на скользкую стезю экстремизма, не желающие адаптироваться к существующей социально-политической системе, избравшие нелегитимные пути и средства ее изменения могут и должны быть обезврежены силовыми методами. Но лишь только усиливая силовую составляющую борьбы с экстремизмом, «выковыривая» их из канализации, нанося им «кинжальные удары», вытаскивая из леса и адаптируя к мирной жизни, можно бороться с отдельными личностями, вставшими на этот скользкий путь. Однако предупредить или окончательно преодолеть экстремизм подобными мерами и средствами невозможно. Предотвратить скольжение отдельного индивида в пропасть экстремизма можно воспитанием, просвещением, образованием, авторитарным воздействием, перевоспитанием, адаптацией к мирной жизни и прочими мерами индивидуального воздействия. А предотвратить экстремистскую метаморфозу нормальной идеологии, распространение такой идеологии как иллюзорно-утопической программы социальных преобразований и деструктивной формы практики невозможно без системных, комплексных социально-экономических реформ, коренным образом меняющих системное качество современного российского общества, устраняющих объективные причины и глубинные истоки экстремизма. Без подобных социальных реформ экстремизм в российском обществе будет воспроизводиться долго, а место одних ликвидированных экстремистов будут занимать другие.

Таким образом, очевидно, что экстремизм как радикальный, чрезвычайный способ социально-политической деятельности, отличается от нерадикального, заурядного способа активности тем, что он является насилием, связанным с прямым уничтожением людей или иной формой физической и нравственно-психологической угрозы жизни людей. Однако специфика экстремизма должна быть установлена не только на уровне экстремистской деятельности, но и на уровне экстремистской идеологии как его исходного компонента. Здесь важно решить, «каковы идейные основы, какова идеологическая мотивация экстремистского действия? Что является критерием экстремистской идеологии? Вот главный вопрос при определении сущности экстремизма» [9, с. 116].

Экстремизм как многомерное социально-политическое явление включает в себя как минимум три существенных момента: экстремистскую идеологию, выступающую основой экстремизма; экстремистскую деятельность как практическую реализацию идеологии экстремизма; экстремистские сообщества и организации, являющиеся формой социальной институализации экстремистской деятельности. Мы исходим из того, что экстремистскими являются только такие социальные действия, которые производятся во имя конкретной экстремистской идеологии. Экстремистский способ поведения существенно отличается от нормального социального действия своим крайним антигуманизмом. Повторимся, указывая на то, что действительным экстремизмом является только мотивированная экстремистской идеологией социальная деятельность. Мы не предлагаем здесь детальный анализ особенностей экстремистской идеологии, так как он представлен нами в монографии «Феномен рели- 
Yakhyaev M.Ya. The Factors of Extremism and Terrorism Reproduction in Contemporary Russia: Comprehensive Analysis. Islamovedenie. V. 7, № 3. P. 26-39

гиозного фанатизма» (Махачкала, 2006) и статье «Специфика фанатической идеологии», опубликованной в журнале «Политика и общество» (2006. № 7).

Помимо экстремистской идеологии и экстремистской деятельности существенным элементом экстремизма, формой его институализации является экстремистская организация. Суть подобной организации состоит в том, что она выступает добровольным сообществом определенной совокупности лиц, объединяющихся на базе конкретной общей идеологии, претерпевшей экстремистскую модификацию и поэтому предстающей теоретическим обоснованием их совместной деятельности, имеющей экстремистскую направленность. Иначе говоря, экстремистская организация - это специфическое объединение людей, имеющее целью реализацию экстремистской идеологии посредством разрушительной для общества и личности террористической деятельности.

Подводя промежуточные итоги, можно сказать, что экстремизм является формой социальной агрессии конкретных субъектов, которая имеет специфическое идеологическое обоснование. И как таковая она направлена на изменение нетерпимых, чрезвычайных, критических с точки зрения носителей экстремистской идеологии условий собственного существования. Подобной агрессией они рассчитывают сохранить собственную социальную, культурную, религиозную идентичностиь воспроизвести традиционные условия своего бытия. Но при этом важно подчеркнуть, что экстремизм как способ социальной активности является всего лишь иллюзорной, утопической, разрушительной формой деятельности, не улучшающей социальное или политическое положение тех или иных групп людей и сил, а только направляющей, канализирующей в ложное, деструктивное русло их стихийную, спонтанную агрессию.

Каковы же основные социальные формы и разновидности экстремизма и каковы действительные индикаторы или критерии их разграничения? Среди отечественных исследователей имеет хождение классификация, разводящая формы экстремизма по сферам социальной деятельности. В соответствии с таким подходом экстремизм считается политическим, если агрессивные действия осуществляются в политической области, национальным, если они совершаются в сфере межнациональных отношений, религиозным, если они проявляются в конфессиональной среде и т. д.

Однако подобные классификации разновидностей экстремизма посредством простого перечисления экстремистских действий или же без анализа конкретного содержания политических, этнонациональных или религиозных идей, лежащих в основе экстремистской направленности социального субъекта, носят чисто формальный характер. Тогда как специфическая суть феномена экстремизм не высвечивается без вскрытия особенностей идей и мотивов, которыми руководствуются субъекты экстремистского поведения. По этой причине иные исследователи пытаются классифицировать разновидности экстремизма, разделяя их и по содержанию идей, захватывающих сознание и действующих на психику экстремиста. Но и при таком подходе отсутствует анализ реального содержания тех идей, которые становятся детерминантой направленности деятельности социального субъекта. И здесь имеет место всего лишь элементарное различение идей по основным формам общественного сознания. Заметим, что если политический экстремизм детерминируется конкретной мировоззренческой идеей или политической идеологией, то в маниакальной устремленности субъекта к политической власти нет какой-либо идеи. Поэтому и стремление к политическому доминированию любой ценой, перевод такого мотива в главную цель поведения следует относить не к экстремизму, а к психическому отклонению. Политический экстремизм имеет место там, где есть устремленность к захвату власти как к необходимому условию реализации конкретного политического проекта, в основе которого лежит определенная экстремистская идеология.

Разграничение форм и разновидностей экстремизма должно осуществляться на основе анализа содержания экстремистской идеологии, оно должно основываться на содержатель- 
Яхьяев М.Я. Факторы воспроизводства экстремизма и терроризма в современной России: комплексный анализ // Исламоведение. 2016. № 3. С. 26-39.

ном анализе такой идеологии. А всего лишь формальное распределение проявлений экстремизма по сферам социального бытия или формам общественного сознания только уводит от искомой истины. При этом важно понимание и того, что не всякая идея может превратиться в «сверхценную» для определенного субъекта и лечь в основу его поведения, а только неординарная, обладающая набором качеств, пригодных для ее трансформации в экстремистскую идеологию. Анализ конкретного содержания экстремистской идеологии должен учитывать и то, что метаморфоза специфической идеи в «сверхценную» идею экстремизма совершается не всегда и не везде, а только при определенных исторических, социально-экономических, политико-правовых и иных условиях. Известно ведь, что конкретные политические, религиозные, национальные идеи существовали долгие времена, но не везде и не всегда они трансформировались в экстремистские политические или религиозные идеологии.

В зависимости от того, какой тип идеи лежит в основе экстремизма, мы можем выделить три основные его формы: религиозный, политический, этнонациональный. Но любая конкретная форма экстремизма зарождается при пересечении двух необходимых предпосылок. Первая предпосылка - это конкретно-историческая ситуация острого социальнополитического конфликта между старым и новым, заметного кризиса традиционного уклада жизни и зарождения нового уклада. Вторая - экстремистская метаморфоза определенной идеологии или же ее формирование на основе синтеза различных элементов нескольких идеологий, или рождение нового экстремистского мировоззрения. В любом случае экстремистская идеология находит себе социальную почву, т. е. конкретных поклонников-носителей и благоприятные условия для распространения. В последующем экстремизм превращается в один из действенных способов социальной активности, приобретая при этом устойчивые организационные формы.

Социальные истоки и причины экстремизма в России

Главной глобальной объективной причиной экстремизма в современном обществе является социально-историческая ситуация тотального отчуждения (социального, экономического, политико-правового, этнонационального, духовно-нравственного, психологического, религиозного и т. д.), в которой реализовывается трансформация индустриального общества в информационно-технологическое постиндустриальное. Иными словами, эта трансформация происходит в условиях капиталистических общественных отношений частной собственности и порождаемых ими многообразных социальных противоречий и конфликтов.

Другим глобальным объективным фактором, порождающим питательную социальную среду для экстремизма, выступает стремление развитых стран мира реализовать идею всемирной капиталистической глобализации выстраиванием всеохватывающей системы транснациональной эксплуатации, идейно-политического доминирования развитых обществ Запада над всем остальным миром. Понятно, что эта политика господства не может не провоцировать совершенно справедливое сопротивление слаборазвитых стран. Она же порождает и острейшие культурные, цивилизационные, конфессиональные, этнические конфликты по всему миру. И эти же конфликты проникают в высокоразвитые страны Запада как результат широкомасштабной миграции рабочей силы из слаборазвитых регионов мира в страны с высоким технологическим развитием. Эти две важнейшие объективные причины проявляются в целом комплексе противоречий и социальных конфликтов, в той или иной мере характерных для каждой страны. Помимо этого, в каждом регионе есть и свои особенные, обусловленные собственной историей и культурой специфические обстоятельства, которые порождают подходящие условия для воспроизводства экстремизма и терроризма.

Научный анализ всего комплекса причин, совокупное действие которых порождает экстремизм в российском обществе, позволяет нам выделить четыре основные группы факторов, провоцирующих готовность и способность определенных социальных групп и конкретных личностей к экстремистской деятельности. Это следующие группы причин: соци- 
Yakhyaev M.Ya. The Factors of Extremism and Terrorism Reproduction in Contemporary Russia: Comprehensive Analysis. Islamovedenie. V. 7, № 3. P. 26-39

ально-экономические, политические, идеологические, психологические (сюда входят и социально-психологические, и индивидуально-психологические факторы, которые взаимосвязаны). Рассмотрим кратко этот комплекс причин, отделяя при этом объективные причины, обусловливающие возможность проявления экстремизма, от причин, способствующих реализации этой возможности, т. е. от причин субъективного плана, благодаря которым отдельные субъекты становятся членами экстремистского сообщества и проводниками экстремистских идей и действий.

К социально-экономическим факторам, порождающим благоприятную социальную почву для воспроизводства экстремизма в России, безусловно, относятся резкое критическое падение уровня жизни населения, понижение его социального статуса и связанных с ним реальных прав и свобод. Значимым здесь является утвердившаяся социальная бесперспективность определенных групп населения, выражающаяся в отсутствии у них реальных экономических возможностей существенно улучшить свое материальное положение, обеспечить себе и членам своей семьи достойное современного общества существование. К этой же группе причин мы отнесем и углубление конфликтов между различными социальными группами, в основе которых лежит несправедливое перераспределение общественного богатства, а также стремление разбогатевших слоев российского общества резко увеличить степень эксплуатации обедневших групп населения.

Важнейшими политическими причинами эскалации экстремизма в российском обществе являются: критическое состояние системы политического управления страной, сложившейся в постсоветский период; половинчатые политико-правовые реформы власти, которые осуществляются в ситуации системного социально-экономического кризиса; усиление политического противостояния различных официальных и оппозиционных группировок, которое является вполне предсказуемой реакцией общества на кризис системы политического управления.

Все эти факторы сформировались как результат социально-экономического и политического кризиса российского общества, который сопровождался ростом напряженности экономического и политического противостояния. И в этой борьбе противоборствующие олигархические круги и политические группировки все больше закручивали и продолжают закручивать и сейчас маховик экстремистских форм политического противостояния. Обобщая причины экстремизма социально-экономического и политического плана, можно сказать, что общей объективной для российского общества причиной активизации экстремизма является системный социальный кризис и усиление всех разновидностей внутрисоциальных, особенно межконфессиональных, противоречий и конфликтов.

Идеологической причиной экстремизма, особенно его религиозно-политической формы, стала не просто выработка экстремистской идеологии, а ее систематическое внедрение в массовое сознание верующих. А это значит, что деятельность теоретиков, разработчиков экстремистской идеологии, системно дополнялась деятельностью пропагандистов-распространителей этой идеологии. И такой деятельности не был поставлен необходимый заслон. Более того, идеологическая работа органов власти и институтов гражданского общества была практически сведена на нет, просветительство уничтожено или сужено до религиозного просветительства, образовательные учреждения лишены возможности ведения воспитательной работы.

Специфическими для России причинами эскалации экстремизма являются прежде всего катастрофические социокультурные следствия разрушительных реформ 90-х годов ХХ века, которые привели к падению жизненного уровня подавляющего большинства населения. Нищета и бесперспективность существования основной массы россиян, невиданное социальное и имущественное расслоение общества, жесточайшая эксплуатация и попрание принципов социальной справедливости - вот те конкретные причины, которые являются благопри- 
Яхьяев М.Я. Факторы воспроизводства экстремизма и терроризма в современной России: комплексный анализ // Исламоведение. 2016. № 3. С. 26-39.

ятной питательной средой для распространения идеологии и психологии экстремизма. Гуманистическая общественная система, сплотившая народы России в монолитное социокультурное единство, исчезла, и ее сменила ситуация полной духовно-нравственной дезориентированности и безыдейного существования личности. А человек не может жить в условиях идейного вакуума и духовно-нравственной дезориентированности. Свято место пусто не бывает. В образовавшийся идейный российский вакуум как из рога изобилия посыпались самые деструктивные идеологические системы, преимущественно нетрадиционного религиозного толка.

Под лозунгами обеспечения конституционного принципа о свободе совести и вероисповедания российская власть реализует очень «странную» политику потакания деструктивной деятельности некоторых религиозных движений нетрадиционного толка, суть которой в предоставлении этим движениям равных прав и возможностей с традиционными религиозными конфессиями. Она не вмешивается в бурный рост разрушительных религиозных культов и сект, не проводит нормативно-правового разграничения между фанатичными деструктивными сектами и религиозными движениями и организациями, имеющими позитивное значение для общества. А отсутствие юридической базы, позволяющей пресекать разрушительную для общества и личности деятельность различных нетрадиционных культов и сект это не что иное, как фактическое пособничество их распространению. Разработанная правовая основа нужна России и для того, чтобы остановить самодеятельность бесчисленных появляющихся как грибы после дождя «новых пророков» российского пошиба. Тех «пророков», которые активно вербуют простодушных россиян в собственные псевдорелигиозные секты, обещая им перманентный духовный комфорт и всевозможные райские блага, а фактически лишая их не только условий нормальной человеческой жизни, но зачастую и самой жизни.

Еще одной специфической причиной эскалации экстремизма в российском обществе является то, что социальные противоречия и конфликты здесь традиционно переводятся в форму межконфессиональных или межнациональных конфликтов. Они нередко искусственно разжигаются и стимулируются как спецслужбами недружественных России государств, так и различными политическими группировками и этническими кланами внутри страны. Подобная стимуляция позволяет определенным политическим силам канализировать социальное недовольство в деструктивное и абсолютно бесперспективное русло религиозной или национальной вражды. Но она же является для геополитических оппонентов России достаточно эффективным средством ее ослабления как геополитического конкурента.

Субъективными причинами воспроизводства экстремизма в российском обществе являются неудовлетворенность россиян низким жизненным уровнем, постоянно испытываемый ими в создавшихся условиях психологический дискомфорт, невозможность удовлетворения смысложизненных идейных ориентаций в условиях отсутствия общенациональной идеи. Если все эти причины являются внутренними для России в целом факторами воспроизводства экстремизма, то сознательная деструктивная идеологическая агрессия, преследующая цель разрушения духовных основ российской цивилизации, выступает внешним фактором эскалации экстремизма.

И наконец, важную роль в активизации экстремизма играли и играют психологические причины, к которым относятся эмоциональные переживания, чувства и настроения, поведенческие установки, выражающиеся в направленности субъекта на жесткие, разрушительные, нелегитимные действия по отношению к мировоззренческим оппонентам, представляемым в качестве основного препятствия реализации целей экстремиста. Индивидуально-психологической причиной экстремизма является особое состояние индивидуального сознания человека. Это такое состояние личности, когда она социально дезинтегрирована и глубоко переживает собственную чуждость и ненужность обществу, малым социальным группам. Ощущение мировоззренческой дезориентации, социального дискомфорта, переживание пол- 
Yakhyaev M.Ya. The Factors of Extremism and Terrorism Reproduction in Contemporary Russia: Comprehensive Analysis. Islamovedenie. V. 7, № 3. P. 26-39

ной социальной беспомощности и бесперспективности личного существования, отсутствие позитивной жизненной перспективы, утрата жизненного оптимизма и подобные им психологические переживания являются мощным индивидуальным психологическим фактором, провоцирующим воспроизводство экстремизма в российском обществе.

При этом важно понимать, что психологические факторы являются не только производными от экономических, социальных, политических и иных причин, порождающих экстремизм, но и значимыми для усугубления влияния других объективных причин. Именно они создают удобную основу для восприятия массовым сознанием идеологии экстремизма, именно через них реализовывается конечный синтез других факторов, порождающих экстремистские сообщества и экстремистскую деятельность.

Объективные и субъективные причины экстремизма необходимо отграничивать от непосредственного повода или толчка к экстремистскому действию. Повод выполняет всего лишь роль спускового механизма или детонатора, вызывающего взрыв сложившейся напряженной социальной ситуации. Поводом к экстремистскому действию в конкретной ситуации может стать что угодно: специальная провокация, индивидуальный или групповой инцидент, разрушительное силовое действие правоохранителей, неудачное политическое решение, техногенная катастрофа и пр.

Таков комплекс объективных и субъективных причин, воспроизводящих экстремизм и терроризм в российском обществе. Системное их действие делает достаточно большое количество российских граждан восприимчивыми к «отраве» экстремистской идеологии, а их постоянное воспроизводство дает основания для неутешительного прогноза о том, что проявления экстремизма еще долго будут будоражить российское общество.

Социальное содержание экстремизма в современном российском обществе характеризуется двумя сложно переплетающимися аспектами. Первый состоит в том, что идеология экстремизма является утопической, иллюзорной и деструктивной формой выражения протеста россиян, лишенных за короткий исторический период времени общенародной собственности, брошенных в нищету, обреченных на постепенное физическое вымирание и как следствие всего этого лишенных былого социального оптимизма. Второй аспект заключается в том, что экстремизм в России проявился в качестве средства идеологического, духовнонравственного, психологического разложения «русской души», того традиционного духовного скрепа, который сплачивал, объединял всех россиян независимо от их национальной или конфессиональной принадлежности, всегда способствовал достойному выходу из сложнейших ситуаций в самые противоречивые периоды исторического бытия российского народа. Оба эти аспекта социального содержания экстремизма позволяют оценить любые формы и разновидности идеологии экстремизма как безусловно отрицательные, неприемлемые, ставящие под угрозу историческую перспективу существования России как самобытной культуры и цивилизации.

Подавление влияния идеологии экстремизма на массовое сознание россиян требует проведения систематической идеологической работы, которая не может и не должна быть сведена исключительно к борьбе с экстремистской идеологией. Как показывает практика, невосприимчивыми к идеологическим установкам экстремизма являются только личности, вобравшие в себя лучшие достижения мировой и отечественной культуры, знающие свою историю, религию, традиции, у которых сформировано прогрессивное научное мировоззрение. Наиболее приемлемыми формами идеологической работы являются научные знания, гуманистическая культура и мораль, а также позитивный потенциал религии и искусства. Однако одно лишь упование на образование, воспитание, пропаганду и просвещение как исключительные средства борьбы с идеологией экстремизма также чревато пагубными последствиями для общества. Поэтому крайне важно не только подавлять силовыми методами проявления экстремизма и вскрывать деструктивную сущность этой идеологии. Важнее создать 
Яхьяев М.Я. Факторы воспроизводства экстремизма и терроризма в современной России: комплексный анализ // Исламоведение. 2016. № 3. С. 26-39.

реальные социальные условия образования и воспитания гуманистически ориентированного россиянина с основательной мировоззренческой, исторической и культурологической подготовкой, способного самостоятельно противостоять идеологической заразе экстремизма и терроризма.

\section{Заключение}

Подводя итоги нашей работы, отметим, что главным направлением противодействия идеологии и практике экстремизма является кардинальное преобразование той экономической, политической, социокультурной, духовно-нравственной ситуации в российском обществе, которая сформировалась как результат антигуманных реформ 90-х годов XX века. Экономическая и социально-политическая система, сложившаяся в России, непрерывно порождает непримиримые, враждующие социальные слои и политические группы, утверждает социальную несправедливость и нищету как норму жизни, плодит правовой беспредел и разгул преступности, маргинализирует общество в целом. Именно эта система провоцирует экстремистские метастазы распространенных в России идеологий (коммунизма, религиозных идеологических систем, консерватизма, либерализма и пр.). Любая идеология является теоретическим выражением реального процесса жизнедеятельности людей, отражением и защитой коренных интересов и потребностей больших групп населения. А действительное бытие отдельных слоев российского населения таково, что разные идеологические системы могут трансформироваться в экстремистские идеологии и предстать выразителями и защитниками интересов тех или иных социальных слоев. На сегодня в России подобная экстремистская метаморфоза произошла с отдельными религиозными системами, в частности, с некоторыми учениями и толками в исламе. Целенаправленная селективная актуализация отдельных положений ислама, акцентирование и произвольная трактовка его некоторых вероучительных источников позволяет вождям-вдохновителям экстремизма, маскирующегося под ислам, заявлять о себе как о защитнике интересов обиженных властью и обществом мусульман. Необходимым предварительным условием предупреждения подобных экстремистских идеологических превращений является решение всего комплекса проблем, накопившихся за последние десятилетия в российском обществе, прежде всего проблем социально-экономического плана.

Реальная, а не декларативная борьба с идеологией и практикой экстремизма может заключаться только в радикальном изменении сложившейся экономической, социальной, политико-правовой, духовно-нравственной ситуации в направлении ее гуманизации. А такое переустройство предполагает: во-первых, проведение социально ориентированных рыночных реформ, способных, если и не устранить, то хотя бы минимизировать социальное неравенство и ужасающее социальное расслоение российского общества; во-вторых, политикоправовую реформу, создающую нормативные предпосылки устранения отчуждения человека от власти; в-третьих, духовно-нравственную реформу, способную кардинально изменить содержание общественной идеологии и психологии. В общем, мы говорим о создании каждому россиянину не только достойных материальных условий существования, но и условий для свободной реализации его творческого потенциала.

Нам необходимо ясное понимание того, что предупреждение экстремизма и борьба с его проявлениями состоит не в репрессиях против экстремистских сообществ или отдельных людей, подверженных заразе экстремизма, а в последовательном культивировании собственной идеологии и гуманистической морали. Идеология экстремизма может быть окончательно вытеснена из сознания наших соотечественников только по мере гуманизации всего российского социума. Она постепенно будет сходить к минимуму по мере приближения российского общества к гуманистическому идеалу. Идеология экстремизма тем меньше проявляется в обществе, чем больше в нем реализуется социальная справедливость и социальное равенство граждан, чем результативнее в нем обеспечиваются основные права и свободы человека. 
Yakhyaev M.Ya. The Factors of Extremism and Terrorism Reproduction in Contemporary Russia: Comprehensive Analysis. Islamovedenie. V. 7, № 3. P. 26-39

\section{Литература}

1. Белокуров Г.И. Мотивационная направленность личности террориста // Юридическая психология. - 2008. - № 2.

2. Генеральная прокуратура Российской Федерации. Портал правовой статистики // http://crimestat.ru/offenses_map.

3. Залужный А.Г. Экстремизм. Сущность и способы противодействия // Современное право. - 2002. - № 12 .

4. Кудряшова И.В. Фундаментализм в пространстве современного мира // Полис. 2002. - № 1 .

5. Матчанова 3.Ш. Мотивация террористической деятельности: криминологический анализ // Исторические, философские, политические и юридические науки, культурология и искусствоведение. Вопросы теории и практики. - Тамбов, 2009. - № 3.

6. Ольшанский Д.В. Психология террора. - М., 2002.

7. Пайн Е.Л. Социальная природа экстремизма и терроризма // Общественные науки и современность. - 2002. - № 4.

8. Русанова O.A. Экстремизм - социологические интерпретации // ib.socio.msu.ru /1/library? $=\mathrm{d}-000-00---0 l o m o n--00-0-0-0$ prompt.

9. Современный политический экстремизм: понятие, истоки, причины, идеология, проблемы, организация, практика, профилактика и противодействие / рук. авт. кол. Дибиров А.-Н.З., Сафаралиев Г.К. - Махачкала: Лотос, 2009.

10. Zinchenko Yury P. Extremism from the perspective of a system approach. // Psychology in Russia: State of the art. - 2014. - V. 7. - Issue 1. DOI: 10.11621/pir.2014.0103

\section{References}

1. Belokurov G.I. Motivatsionnaya napravlennost' lichnosti terrorista [Motivational orientation of the individual terrorist] Yuridicheskaya psikhologiya. [Legal psychology]. - 2008. № 2 .

2. General'naya prokuratura Rossiiskoi Federatsii [The General Prosecutor of the Russian Federation.] Portal pravovoi statistiki // http://crimestat.ru/offenses_map

3. Zaluzhnyi A.G. Ekstremizm. Sushchnost' i sposoby protivodeistviya [Extremism. The essence and ways of counteraction] Sovremennoe pravo. [Modern law]. - 2002. - № 12.

4. Kudryashova I.V. Fundamentalizm v prostranstve sovremennogo mira [Fundamentalism in the modern world] Polis. - 2002. - № 1.

5. Matchanova Z.Sh. Motivatsiya terroristicheskoi deyatel'nosti: kriminologicheskii analiz [Activities of terrorist Motivation: a criminological analysis] Istoricheskie, filosofskie, politi-cheskie i yuridicheskie nauki, kul'turologiya i iskusstvovedenie. Voprosy teorii i praktiki. [Historical, philosophical, politi-cal and juridical Sciences, Culturology and study of art. Issues of theory and practice]. - 2009. - № 3. S. 16.

6. Ol'shanskii D.V. Psikhologiya terrora. [Psychology of terror]. - Moscow, 2002. -

7. Pain E.L. Sotsial'naya priroda ekstremizma i terrorizma [The Social nature of extremism and terrorism] Obshchestvennye nauki i sovremennost' [Public Sciences and modernity]. 2002. - № 4 .

8. Rusanova O.A. Ekstremizm - sotsiologicheskie interpretatsii [The Extremism - a sociological interpretation] ib.socio.msu.ru /1/library? $=\mathrm{d}-000-00---010 m o n--00-0-0-0 p r o m p t$ 
Яхьяев М.Я. Факторы воспроизводства экстремизма и терроризма в современной России: комплексный анализ // Исламоведение. 2016. № 3. С. 26-39.

9. Sovremennyi politicheskii ekstremizm: ponyatie, istoki, prichiny, ideologiya, problemy, organizatsiya, praktika, profilaktika i protivodeistvie. [Modern political extremism: concept, sources, causes, ideology, problems, organization, practice, prevention teak and opposition] Ruk. avt. kol. Dibirov A.-N.Z., Safaraliev G.K. - Makhachkala: Lotos, 2009.

10. Zinchenko Yury P. Extremism from the perspective of a system approach Psychology in Russia: State of the art. - 2014. - 7 (1). S. 23-33. 